\title{
Analisa Komputasi Paralel Mengurutan Data Dengan Metode Radix Dan Selection
}

\author{
Favorisen R. Lumbanraja, Aristoteles, Nadila Rizqi Muttaqina \\ Jurusan Ilmu Komputer FMIPA Universitas Lampung, Bandar Lampung 35145 \\ *E-mail: nadila.rizqi1135@students.unila.ac.id
}

\begin{abstract}
Increasing computing power is now achieved by replacing the programming paradigm with parallel programming. Parallel computing is a method of solving problems by dividing the computational load into small parts of the computation sub-process. This study describes the comparative analysis of parallel computations in the Selection Sort and Radix Sort algorithms. The data used are in the form of whole numbers and decimal numbers totaling 100 to 2 million data. The test was carried out with three scenarios, namely using two processors, four processors, and 3 computers connected to each other via a LAN network. The results showed that the parallel Selection Sort algorithm for small data was better than the parallel Radix Sort. On the other hand, parallel Radix Sort is better for millions of data than Selection Sort.
\end{abstract}

Keywords: parallel computing, serial computing, selection sort, radix sort, grid computing.

\section{PENDAHULUAN}

Pada tahun 1965, Gordon E. Moore salah satu pendiri Intel, membuat prediksi bahwa kompleksitas sebuah mikroporsesor akan mengalami peningkatan dua kali lipat setiap dua tahun sekali. Namun saat ini yang terjadi clock rate tidak meningkat sebanyak sebelumnya dikarenakan keterbatasan dari material-material penyusun chip itu sendiri.

Penyediaan sumber daya komputasi yang powerful didorong oleh kebutuhan pengaksesan informasi kapanpun dan dimanapun. Peningkatan kekuatan komputasi saat ini didapat dengan mengganti paradigma pemrograman menjadi pemrograman paralel dengan cara memecah proses menjadi sub-proses yang bisa memaksimalkan kapasitas core dan memory. Para peneliti telah menggunakan dua pendekatan di bidang komputasi berkinerja tinggi yaitu supercomputer dan multicomputer ${ }^{1)}$.

Supercomputer yaitu membangun sebuah komputer dengan kemampuan perhitungan dan kapasitas tinggi dibandingkan dengan komputer biasa ${ }^{2}$. Pendekatan ini umumnya berharga sangat mahal yang dapat dimiliki oleh segelintir pihak saja, namun akan menghasilkan sebuah komputer yang berkinerja tinggi. Sedangkan multicomputer yaitu membangun sebuah sistem yang terdiri dari beberapa komputer independen dihubungkan oleh jaringan telekomunikasi atau jaringan komputer $^{3}$. Pendekatan kedua ini terdiri dari beberapa komputer yang tergabung dan terkonfigurasi perangkat lunak yang digunakan dan menghasilkan kinerja yang bervariasi tergantung jumlah komputernya, dengan harga yang lebih terjangkau dibandingkan supercomputer ${ }^{4)}$.

Pengolahan data yang baik sangat diperlukan dalam pengaksesan data yang baik, kuat, dan cepat pula. Mengenai pengolahan data, pengurutan data memegang peranan penting yang banyak dipertimbangkan agar keseluruhan permasalahan menjadi lebih baik dan cepat untuk diselesaikan sehingga menghasilkan data yang akurat ${ }^{5)}$. 
Pengurutan (sorting) merupakan suatu proses mengurutkan data dengan proses yang terjadi yaitu perbandingan data dan pertukaran data berdasarkan suatu aturan tertentu, sehingga tersusun secara teratur sesuai dengan aturan tersebut ${ }^{6}$. Pada dasarnya ada dua macam aturan pengurutan yang biasa digunakan yaitu ascending (pengurutan data terkecil ke terbesar) dan descending (pengurutan data terbesar ke terkecil) $)^{7}$.

\section{METODOLOGI}

\section{a. Komputasi Paralel}

Komputasi paralel adalah metode komputasi untuk menyelesaikan permasalah komputasi dengan membagi beban komputasi ke dalam beberapa bagian kecil sub proses komputasi, dimana sub komputasi tersebut dijalankan pada prosesor yang berbeda secara bersamaan dan saling berinteraksi satu sama lain $^{8}$. Tujuan dari komputasi paralel adalah meningkatkan kinerja komputer dalam menyelesaikan berbagai masalah dengan membagi sebuah masalah besar ke dalam beberapa masalah kecil, sehingga hal tersebut membuat kinerja menjadi cepat ${ }^{9)}$.

Peningkatan kecepatan dalam komputasi paralel menunjukkan seberapa cepat proses komputasi paralel dibandingkan dengan komputasi serial. Pada dasarnya, peningkatan kecepatan (Speed Up) dan Efisiensi dirumuskan pada persamaan (1)Speed Up dan (2)Efisiensi berikut ini.

$$
\begin{aligned}
& S=\frac{T S}{T P} \\
& E=\frac{S}{P}
\end{aligned}
$$

Keterangan:

TS : Waktu eksekusi dari komputasi serial

$T P$ : Waktu eksekusi dari komputasi paralel menggunakan sebanyak P (prosesor)

$S \quad$ : Peningkatan kecepatan (Speed $U p)$

E : Efisiensi

\section{b. Message Passing Interface (MPI)}

Implementasi standar dari model "message passing" komputasi yaitu Message Passing Interface (MPI). MPI adalah sebuah komputasi paralel terdiri dari sejumlah proses yang masing-masing bekerja pada beberapa data lokal ${ }^{10}$. Setiap proses mempunyai variable lokal, dan tidak ada mekanisme memori lain bisa diakses secara langsung oleh suatu proses. Message Passing Interface mempunyai tujuan yaitu untuk menyediakan standar pemakaian secara luas untuk menulis program pertukaran pesan ${ }^{11)}$.

Message Passing Interface (MPI) adalah suatu spesifikasi library pemrograman untuk meneruskan pesan (message-passing), yang diajukan sebagai standar oleh berbagai komite dari vendor, pelaksana, dan pemakai. Suatu proses (process) merupakan sebuah pencacah program dan ruang alamat yang dapat memiliki banyak thread (pencacah program dan memori lokal) yang saling berbagi ruang alamat. Dalam hal ini, MPI berfungsi sebagai alat komunikasi di antara proses yang saling memiliki ruang terpisah terutama komunikasi berupa sinkronisasi dan perpindahan data antar proses. Konsep MPI yang digunakan dapat dilihat pada Gambar 1. 
Vol. 8 No. 2, 2020

(C2020 Ilmu Komputer Unila Publishing Network all rights reserved

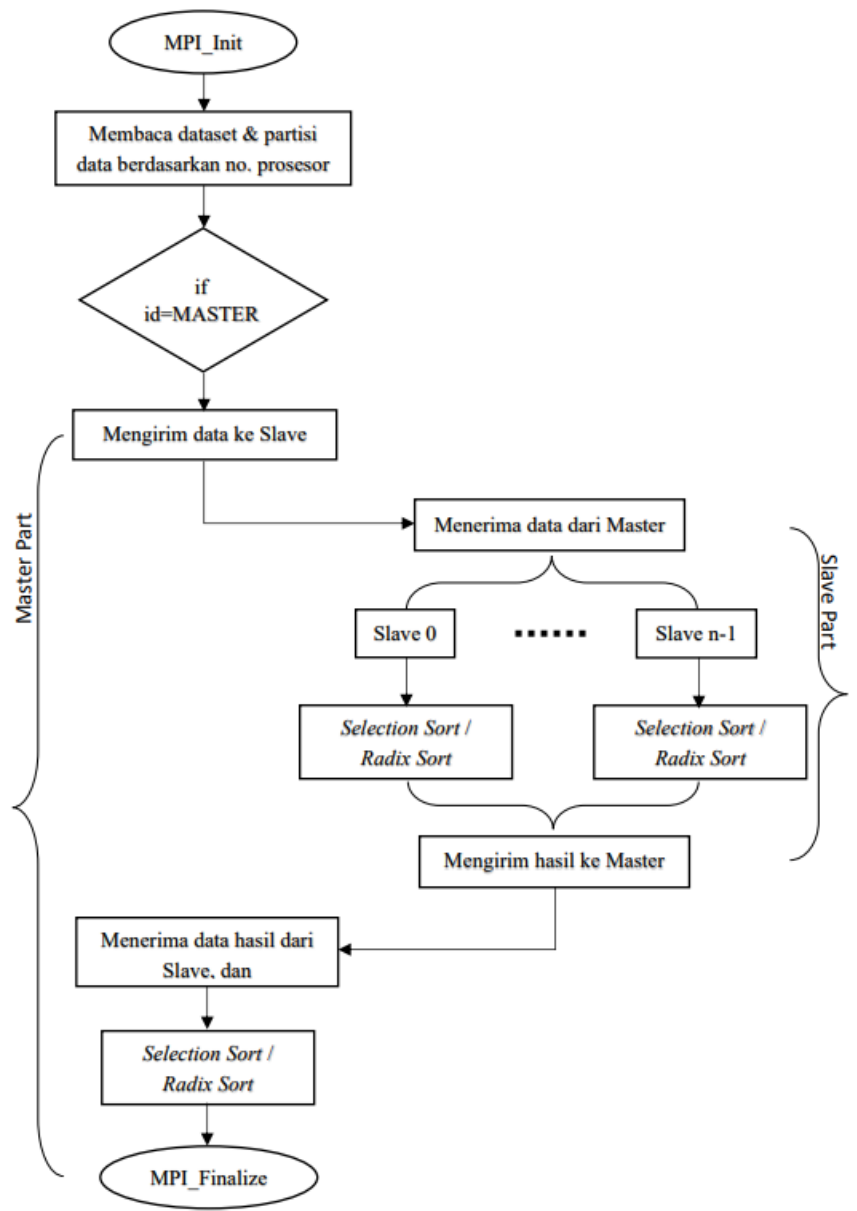

Gambar 1. Konsep MPI

\section{c. Algoritma Selection Sort}

Selection Sort merupakan suatu metode pengurutan yang membandingkan elemen paling kiri (elemen awal) dengan elemen-elemen berikutnya sampai dengan elemen yang terakhir pada setiap tahapnya ${ }^{12}$. Pada saat membandingkan, jika terdapat elemen lain yang lebih kecil (pengurutan ascending) atau lebih besar (pengurutan descending) dari elemen awal maka dicatat posisinya dan langsung ditukar. Proses pengurutan dilakukan terus hingga tahap terakhir dan tidak ada lagi pertukaran data. Kompleksitas dari algoritma Selection Sort adalah $\mathrm{O}\left(\mathrm{n}^{2}\right)^{13)}$. Ilustrasi algoritma Selection Sort dapat dilihat pada Gambar 2 dan Gambar 3.

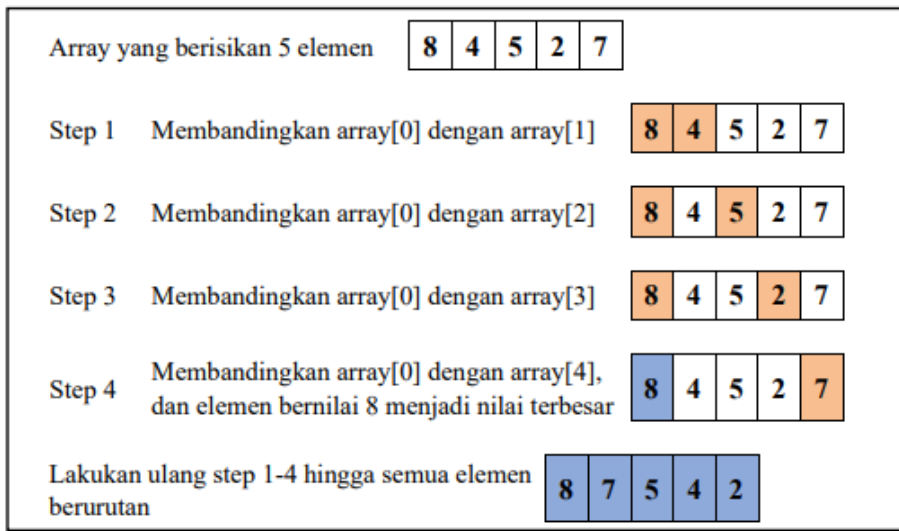

Gambar 2. Ilustrasi algoritma Selection Sort secara serial 
Vol. 8 No. 2, 2020

Jurnal Komputasi

(C2020 Ilmu Komputer Unila Publishing Network all rights reserved

\begin{tabular}{|c|c|c|c|c|c|c|c|c|c|c|c|c|c|}
\hline Array & yang berisikan 6 elemen & 8 & 4 & 5 & 2 & 37 & & & & & & & \\
\hline Step 1 & Membagi menjadi 2 partisi & & & & & & 8 & & & 5 & 2 & 3 & 7 \\
\hline Step 2 & $\begin{array}{l}\text { Membandingkan nilai MAX } \\
\text { elemen yang lebih besar ak }\end{array}$ & $\begin{array}{l}\text { arti } \\
\text { dite }\end{array}$ & kir & $\begin{array}{l}\text { de } \\
\text { kar }\end{array}$ & $\begin{array}{l}\text { gan } 1 \\
\text { di arr }\end{array}$ & $\begin{array}{l}\text { kanan } \\
\text { ay[0] }\end{array}$ & 8 & & & 5 & 2 & 3 & 7 \\
\hline Step 3 & $\begin{array}{l}\text { Membandingkan nilai MIN } \\
\text { elemen yang lebih kecil aka }\end{array}$ & $\begin{array}{l}\text { rtis } \\
\text { liter }\end{array}$ & kiri & & $\begin{array}{l}\text { gan } k \\
\text { di arr }\end{array}$ & $\begin{array}{l}\text { anan, } \\
\text { ay[5] }\end{array}$ & 8 & & & 5 & 2 & 3 & 7 \\
\hline Step 4 & $\begin{array}{l}\text { Elemen dengan nilai } 8 \text { dan } \\
\text { dan terkecil }\end{array}$ & nenj & di & & & & 8 & & & 5 & 7 & 3 & 2 \\
\hline Lakul & kan ulang step $1-4$ hingga ser & a elc & men & b & uruta & $n$ & 7 & s. & & & & 2 & \\
\hline
\end{tabular}

Gambar 3. Ilustrasi algoritma Selection Sort secara paralel

\section{d. Algoritma Radix Sort}

Radix Sort adalah metode pengurutan yang mengurutkan nilai tanpa melakukan perbandingan pada data yang dimasukkan ${ }^{14)}$. Terdapat 2 jenis Radix Sort yaitu Least Significant Digit (LSD) dan Most Significant Digit (MSD). MSD bekerja dengan cara mengurutkan nilai-nilai input berdasarkan radix (digit) pertama, lalu pengurutan dilakukan lagi berdasarkan radix kedua, begitu seterusnya hingga data terurut. Sebaliknya, LSD berdasarkan digit terakhir hingga pertama. Kompleksitas algoritma Radix Sort yaitu $\mathrm{O}(\mathrm{n}+\mathrm{kb})$ atau $\mathrm{O}(\mathrm{n})^{14)}$. Simulasi algoritma Radix Sort ditunjukkan pada Gambar 4 dan Gambar 5.

\begin{tabular}{|c|c|c|c|c|c|c|c|c|c|c|c|}
\hline \multicolumn{12}{|c|}{ Array berisi 12 elemen } \\
\hline 8 & 24 & 35 & 22 & 3 & 11 & 10 & 20 & 19 & 31 & 7 & 1 \\
\hline \multicolumn{12}{|c|}{ Mengurutkan berdasarkan digit kedua } \\
\hline $0 \underline{8}$ & $2 \underline{4}$ & $3 \underline{5}$ & 22 & $\mathbf{0 3}$ & $1 \underline{1}$ & $1 \underline{0}$ & $2 \underline{0}$ & $1 \underline{9}$ & $3 \underline{1}$ & $0 \underline{7}$ & $0 \underline{1}$ \\
\hline \multicolumn{12}{|c|}{$\begin{array}{l}\text { Setelah terurut berdasarkan digit kedua, lalu diurutkan } \\
\text { berdasarkan digit pertama }\end{array}$} \\
\hline$\underline{\mathbf{1 0}}$ & $\underline{\mathbf{2} 0}$ & $\underline{11}$ & $\underline{\mathbf{3} 1}$ & $\underline{01}$ & $\underline{22}$ & $\underline{\mathbf{0} 3}$ & $\underline{24}$ & $\underline{35}$ & $\underline{\mathbf{0}} 7$ & $\underline{08}$ & $\underline{19}$ \\
\hline \multicolumn{12}{|c|}{ Hasil array yang sudah terurut secara ascending } \\
\hline 01 & 03 & 07 & 08 & 10 & 11 & 19 & 20 & 22 & 24 & 31 & 35 \\
\hline
\end{tabular}

Gambar 4. Ilustrasi algoritma Radix Sort secara serial

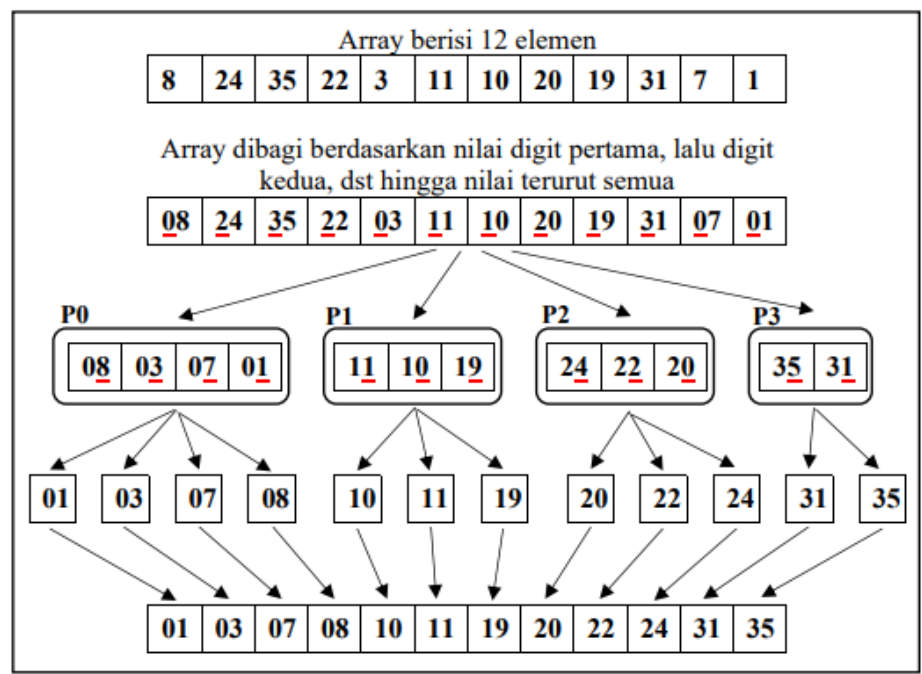

Gambar 5. Ilustrasi algoritma Radix Sort secara paralel 
Vol. 8 No. 2, 2020

Jurnal Komputasi

(C2020 Ilmu Komputer Unila Publishing Network all rights reserved

\section{e. Tahapan Penelitian}

Tahapan penelitian yang dilakukan yaitu studi literatur, analisis kebutuhan, persiapan data, pembuatan program, pelaksanaan pengujian, analisis hasil pengujian, dan yang terakhir penyelesaian laporan. Adapun lebih jelasnya tahapan penelitian ditunjukkan dalam bentuk flowchart pada Gambar 6.

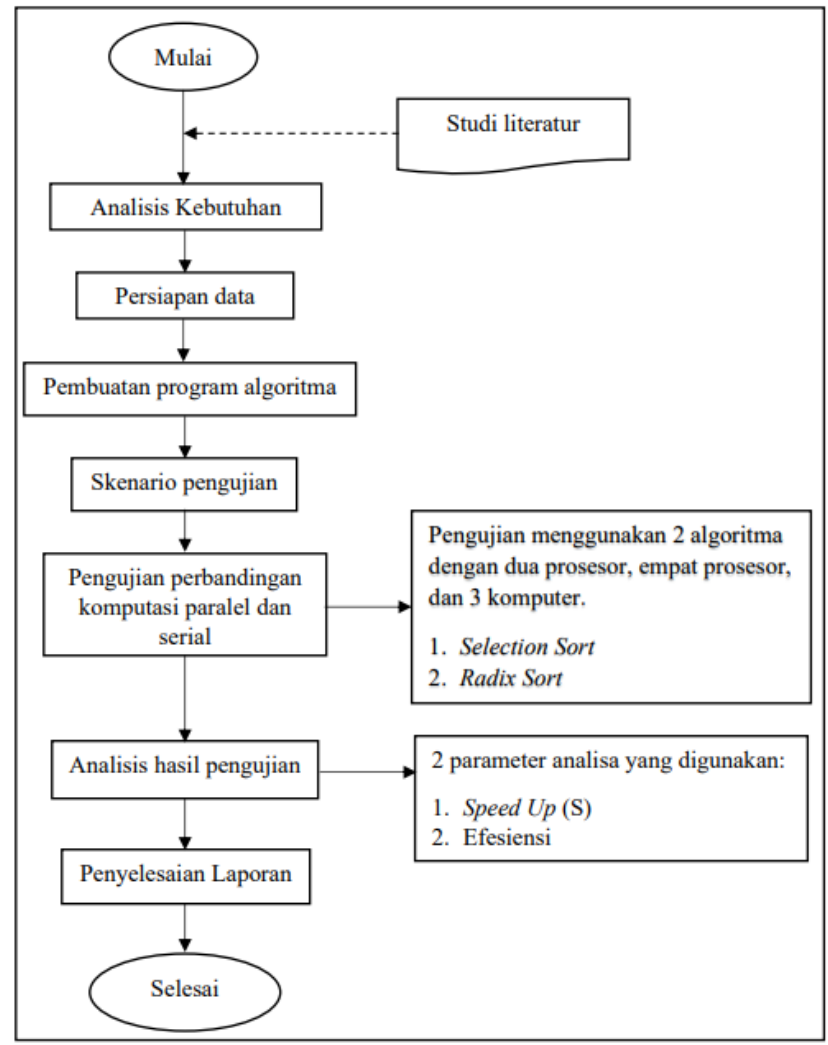

Gambar 6. Flowchart tahapan penelitian

\section{i. Studi Literatur}

Tahapan ini yaitu melakukan pencarian terhadap berbagai sumber tertulis, baik berupa bukubuku, arsip, majalah, artikel, jurnal, paper, atau dokumen-dokumen yang relevan dengan permasalahan komputasi paralel serta algoritma Selection Sort dan Radix Sort. Tujuan dari tahapan ini adalah memperoleh referensi teori serta penelitian yang telah dilakukan sebelumnya, sehingga dapat dijadikan rujukan untuk memperkuat argumentasi-argumentasi yang ada.

\section{ii. Analisis Kebutuhan}

Sebelum melakukan analisis dan pengujian perlu adanya suatu rumusan dan perencanaan yang jelas, sehingga dapat ditentukan tujuan dari pengujian yang dilakukan. Penelitian ini dilakukan dengan 2 pengujian, pertama pengujian menggunakan satu komputer dengan banyak prosesor, dan kedua pengujian menggunakan tiga komputer yang saling terhubung menggunakan jaringan LAN (Local Arena Network) dengan kata lain disebut grid computing (komputasi grid). Desain rancangan sistem grid yang dibuat dapat dilihat pada Gambar 7. 


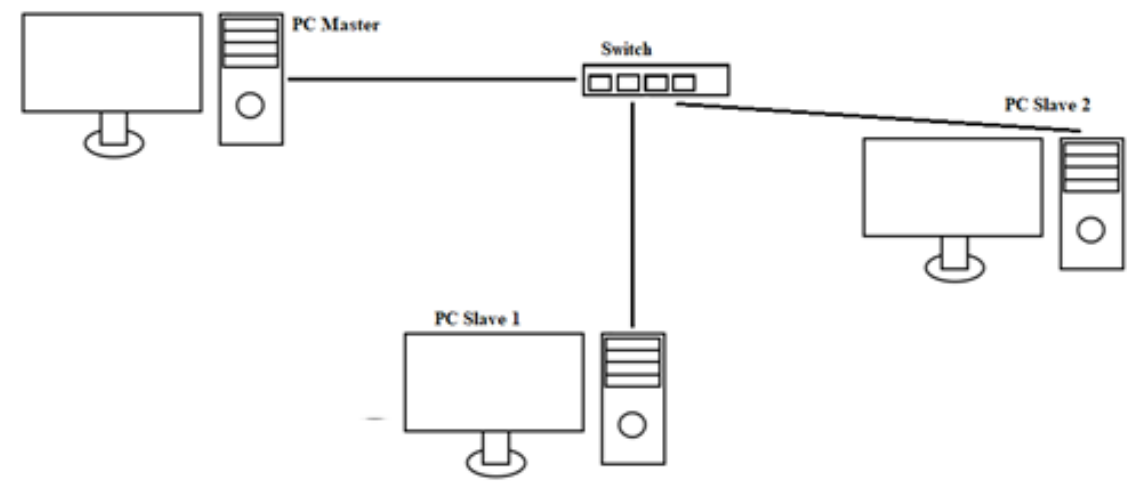

Gambar 7. Desain rancangan sistem grid computing

Pada perancangannya, tiap-tiap komputer akan diinstal beberapa perangkat lunak yang digunakan untuk membangun sistem komputasi grid. Sebagai perinciannya dijelaskan sebagai berikut.

a. Komputer master akan diinstal sistem operasi LINUX, Net-Tools, SSH (Secure Shell), NFS Server (Network File System), teks editor Gedit, perekam layar Kazam, dan OpenMPI sebagai API untuk menjalankan pemrosesan paralel.

b. Komputer slave akan diinstal sistem operasi LINUX, Net-Tools, SSH (Secure Shell), NFS Client (Network File System), teks editor Gedit, perekam layar Kazam, dan OpenMPI sebagai API untuk menjalankan pemrosesan paralel.

\section{iii. Persiapan Data}

Data yang digunakan adalah data bilangan bulat dan bilangan desimal yang disimpan di dalam file teks (.txt) dengan masing-masing jumlah data yang ingin diuji. Jumlah data berisi ratusan, ribuan, puluh ribuan, hingga jutaan.

\section{iv. Pembuatan Program Algoritma}

Program algoritma dibuat menjadi empat program yaitu program algoritma Selection Sort untuk bilangan bulat, Selection Sort untuk bilangan desimal, Radix Sort untuk bilangan bulat, serta Radix Sort untuk bilangan desimal.

\section{v. Skenario Pengujian}

Pengujian dilakukan dengan membandingkan nilai Speed Up dan Efisiensi dari sejumlah prosesor dengan banyaknya data yang diurutkan. Pengujian juga dilakukan dengan memperlihatkan hasil pengujian dengan menggunakan satu komputer dan 3 komputer. Pada pengujian satu komputer dilakukan dengan melakukan simulasi terhadap dua prosesor dan empat prosesor, sedangkan pengujian dengan tiga komputer menggunakan 12 prosesor.

Pengujian dengan tiga komputer ini, setiap PC terinstal sistem operasi Linux dengan dual boot yang sistem operasi utamanya yaitu Windows 10. Adapun skenario pengujian yang dilakukan dapat dilihat pada Tabel 1 sebagai berikut.

Tabel 1. Skenario pengujian

\begin{tabular}{|c|c|c|c|c|}
\hline No & Jumlah & Banyak Data (n) & \multicolumn{2}{|c|}{ Parameter Analisa } \\
\hline 1. & $\mathrm{p}=2$ & \multirow{3}{*}{$\begin{array}{l}100,1000,10000,50000, \\
100000,5000000,1000000, \\
2000000 .\end{array}$} & \multirow{3}{*}{ Speed Up (S) } & \multirow{3}{*}{ Efisiensi (E) } \\
\hline 2. & $\mathrm{p}=4$ & & & \\
\hline 3. & $\begin{array}{l}3 \text { Komputer, } p \\
=12\end{array}$ & & & \\
\hline
\end{tabular}


Vol. 8 No. 2, 2020

Jurnal Komputasi

(C2020 Ilmu Komputer Unila Publishing Network all rights reserved

\section{vi. Pengujian}

Tahapan ini merupakan pelaksanaan pengujian yang membandingkan antara komputasi secara paralel dengan serial. Sebelum melakukan pengujian, komputer yang digunakan akan dilakukan penginstalan serta konfigurasi agar saling terhubung melalui jaringan LAN. Tahapan penginstalan komputer sebagai berikut.

a. Menginstal sistem operasi Linux Ubuntu versi 20.04 LTS.

b. Menginstal SSH (Secure Shell) yang berfungsi agar komputer master dapat mengakses komputer slave A dan slave B melalui koneksi yang terenkripsi.

c. Menginstal NFS (Network File System) yang berfungsi untuk sharing file dari komputer master ke komputer slave.

d. Menginstal OpenMPI yang berfungsi sebagai library program paralel.

Pengujian terhadap penelitian ini difokuskan pada dua aspek yaitu Efisiensi dan Speed Up yang merupakan nilai yang diperoleh dari pembagian waktu proses komputasi serial dengan waktu proses komputasi paralel. Efisiensi pada pengujian ini adalah pembagian antara nilai Speed Up dengan banyaknya prosesor yang digunakan.

\section{vii. Analisis Hasil Pengujian}

Tahap ini yaitu menganalisis dengan menghitung nilai Speed Up dan Efisiensi dari pemrograman secara serial dan paralel. Waktu eksekusi secara serial dan paralel ini yang akan dijadikan sebagai parameter untuk mendapatkan nilai Speed Up dan Efisiensi algoritma Selection Sort dan Radix Sort. Setelah mendapatkan nilai Speed Up dan Efisiensi, selanjutnya yaitu membandingkan nilai tersebut dari ketiga skenario pengujian yang telah dilakukan.

\section{viii. Penyelesaian Laporan}

Penulisan laporan ditujukan untuk dokumentasi seluruh kegiatan penelitian analisis perbandingan komputasi paralel dan serial pada algoritma Selection Sort dan Radix Sort di Laboratorium RLP Jurusan Ilmu Komputer Universitas Lampung.

\section{PEMBAHASAN}

\section{a. Pengujian}

Pada penelitian ini pengujian dilaksanakan selama 8 hari dari tanggal 7 September 2020 hingga 18 September 2020 di Laboratorium Rekayasa Perangkat Lunak (RPL) Jurusan Ilmu Komputer Fakultas Matematika dan Ilmu Pengetahuan Alam Universitas Lampung. Detail tahapan pelaksanaan pengujian sebagai berikut.

1. Menginstall Sistem Operasi (SO) Linux Ubuntu versi 20.04 LTS di komputer ke-1 sebagai PC Master dan komputer ke-2 serta ke-3 sebagai PC Slave A dan B.

2. Menginstall SSH (Secure Shell), NFS (Network File System), dan OpenMPI.

3. Running program algoritma Selection Sort dan Radix Sort.

4. Mencatat waktu eksekusi baik secara paralel maupun serial.

5. Hitung Speed Up dan Efisiensi dari masing-masing data.

Tabel 2. Spesifikasi komputer

\begin{tabular}{ll}
\hline \multicolumn{1}{c}{ Komponen } & \multicolumn{1}{c}{ Spesifikasi } \\
\hline Prosesor & Intel I7-8550U 1.8 \\
RAM & $8 \mathrm{~GB}$ \\
Sistem Operasi & Linux \\
\hline
\end{tabular}

Tabel 3. Kegiatan pengujian 
(C2020 Ilmu Komputer Unila Publishing Network all rights reserved

\begin{tabular}{|c|c|c|c|}
\hline No & Tanggal & Hari & Kegiatan \\
\hline 1. & 7 September 2020 & Senin & $\begin{array}{l}\text { Menginstall Sistem Operasi (SO) Linux Ubuntu versi } \\
\text { 20.04 LTS di } 3 \text { komputer (dual boot). }\end{array}$ \\
\hline 2. & 8 September 2020 & Selasa & Menginstall SSH, NFS, dan OpenMPI. \\
\hline 3. & 9 September 2020 & Rabu & $\begin{array}{l}\text { - Running program algoritma Selection Sort secara } \\
\text { serial maupun paralel. } \\
\text { - Mengubah coding program algoritma Selection Sort } \\
\text { karena terdapat kejanggalan dari hasil running time } \\
\text { yang sudah dilakukan. } \\
\text { - Running ulang program algoritma Selection Sort. }\end{array}$ \\
\hline 4. & 14 September 2020 & Senin & $\begin{array}{l}\text { - Running data bilangan bulat dan decimal } \\
\text { menggunakan algoritma Selection Sort. } \\
\text { - Running program algoritma Radix Sort. }\end{array}$ \\
\hline 5. & 15 September 2020 & Selasa & $\begin{array}{l}\text { - Running data algoritma Selection Sort. } \\
\text { - Mengubah coding program dari algoritma Radix } \\
\text { Sort karena sebelumnya terdapat masalah. } \\
\text { - Running data } 7 \text { juta untuk algoritma Selection Sort } \\
\text { menggunakan } 3 \text { komputer (komputer dibiarkan } \\
\text { hidup). }\end{array}$ \\
\hline 6. & 16 September 2020 & Rabu & $\begin{array}{l}\text { - Running data } 7 \text { juta untuk algoritma Selection Sort } \\
\text { menggunakan } 3 \text { komputer belum selesai hingga sore } \\
\text { hari. }\end{array}$ \\
\hline 7. & 17 September 2020 & Kamis & $\begin{array}{l}\text { - Running data } 7 \text { juta tidak kunjung selesai hingga } \\
\text { siang hari. } \\
\text { - Melaporkan kondisi running data } 7 \text { juta yang juga } \\
\text { belum selesai hingga dua hari kepada pak } \\
\text { Aristoteles. } \\
\text { - Memutuskan pengurangan data yang diuji menjadi } \\
\text { maksimal } 2 \text { juta saja. } \\
\text { - Running data algoritma Selection Sort dan Radix } \\
\text { Sort. }\end{array}$ \\
\hline 8. & 18 September 2020 & Jumat & - Menyelesaikan running data yang belum. \\
\hline
\end{tabular}

\section{b. Hasil Pengujian}

Pada tahap ini akan disampaikan mengenai hasil pengujian dan analisa keempat program yakni pengurutan data bilangan bulat dan bilangan desimal dengan menggunakan algoritma Selection Sort dan Radix Sort baik yang dilakukan secara serial maupun secara paralel. Pengujian dilakukan menggunakan suatu skenario pengujian yang dapat membandingkan hasil dari keempat program tersebut.

Hasil pengujian dilakukan dengan menghitung nilai Speed Up dan Efisiensi penggunaan pemrograman secara serial dan paralel. Waktu eksekusi secara serial dan paralel ini yang akan dijadikan sebagai parameter untuk mendapatkan nilai Speed Up dan Efisiensi algoritma Selection Sort dan Radix Sort.

\section{i. Pengujian Algoritma Selection Sort $(\mathrm{p}=2)$}

Hasil pengujian dari algoritma Selection Sort menggunakan dua prosesor dengan menguji data bilangan bulat dan bilangan desimal dapat dilihat pada Tabel 4 .

Tabel 4. Hasil pengujian algoritma Selection Sort dengan dua prosesor

\begin{tabular}{lccccc} 
Jenis & Banyak & (TP) & Speed Up (S) & Efisiensi \\
Data & Data (n) & TS/TP & $\begin{array}{c}\text { TS } \\
\text { (S) }\end{array}$ \\
\hline
\end{tabular}


C2020 Ilmu Komputer Unila Publishing Network all rights reserved

\begin{tabular}{|c|c|c|c|c|c|}
\hline \multirow{9}{*}{$\begin{array}{l}\text { Bilangan } \\
\text { bulat }\end{array}$} & 100 & 0.000203 & 0.000076 & 0.37438424 & 0.18719212 \\
\hline & 1000 & 0.006614 & 0.005142 & 0.77744179 & 0.3887209 \\
\hline & 10000 & 0.132795 & 0.135117 & 1.0174856 & 0.5087428 \\
\hline & 50000 & 3.309182 & 2.95984 & 0.89443252 & 0.44721626 \\
\hline & 100000 & 13.545971 & 11.834191 & 0.8736318 & 0.4368159 \\
\hline & 500000 & 345.072925 & 321.197037 & 0.93080915 & 0.46540458 \\
\hline & 1000000 & 1382.66316 & 1318.4576 & 0.95356385 & 0.47678192 \\
\hline & 2000000 & 5773.86105 & 5282.46807 & 0.91489352 & 0.45744676 \\
\hline & Rata-rata & 939.823988 & 867.132135 & 0.84208031 & 0.42104015 \\
\hline \multirow{9}{*}{$\begin{array}{l}\text { Bilangan } \\
\text { desimal }\end{array}$} & 100 & 0.000183 & 0.000075 & 0.40983607 & 0.20491803 \\
\hline & 1000 & 0.006609 & 0.005154 & 0.77984567 & 0.38992283 \\
\hline & 10000 & 0.130703 & 0.132766 & 1.01578388 & 0.50789194 \\
\hline & 50000 & 3.152981 & 2.811933 & 0.89183316 & 0.44591658 \\
\hline & 100000 & 13.215738 & 11.299437 & 0.85499856 & 0.42749928 \\
\hline & 500000 & 339.485791 & 315.334428 & 0.92885899 & 0.46442949 \\
\hline & 1000000 & 1408.70096 & 1299.62982 & 0.92257325 & 0.46128662 \\
\hline & 2000000 & 6134.89913 & 5548.95054 & 0.90448929 & 0.45224464 \\
\hline & Rata-rata & 987.449011 & 897.270518 & 0.83852736 & 0.41926368 \\
\hline
\end{tabular}

\section{ii. Analisis Pengujian Algoritma Selection Sort dengan Dua Prosesor}

Pada Tabel 4 dapat dilihat bahwa untuk jumlah data 10.000 waktu komputasi secara paralel lebih, tetapi untuk data lainnya dari 100 hingga 2.000.000 waktu komputasi secara serial lebih kecil. Speed Up mengalami peningkatan dan penurunan seiring bertambahnya jumlah data, seperti peningkatan nilai Speed $U p$ dari data 1.000 ke 10.000, namun menurun pada data 50.000. Terlihat bahwa nilai Speed Up tidak konstan naik atau turun. Hal ini berarti bahwa Algoritma Selection Sort dengan dua prosesor tidak cocok untuk komputasi secara paralel, terbukti dari hasil Speed $U p$ yang didapat hampir keseluruhan masih menunjukkan nilai dibawah 1 yang berarti waktu komputasi secara serial masih lebih kecil dibandingkan waktu komputasi secara paralel.

\section{iii. Pengujian Algoritma Selection Sort $(p=4)$}

Hasil pengujian dari algoritma Selection Sort menggunakan empat prosesor dengan menguji data bilangan bulat dan bilangan desimal dapat dilihat pada Tabel 5 .

Tabel 5. Hasil pengujian algoritma Selection Sort dengan empat prosesor

\begin{tabular}{|c|c|c|c|c|c|}
\hline Jenis Data & $\begin{array}{l}\text { Banyak } \\
\text { Data (n) }\end{array}$ & (TP) & (TS) & $\begin{array}{c}\text { Speed Up }(\mathrm{S}) \\
\text { TS/TP }\end{array}$ & $\begin{array}{c}\text { Efisiensi } \\
(\mathbf{S} / \mathbf{p})\end{array}$ \\
\hline \multirow{9}{*}{$\begin{array}{l}\text { Bilangan } \\
\text { bulat }\end{array}$} & 100 & 0.000108 & 0.000041 & 0.37962963 & 0.09490741 \\
\hline & 1000 & 0.002249 & 0.002545 & 1.13161405 & 0.28290351 \\
\hline & 10000 & 0.115987 & 0.149094 & 1.28543716 & 0.32135929 \\
\hline & 50000 & 2.872051 & 3.746832 & 1.30458408 & 0.32614602 \\
\hline & 100000 & 12.554171 & 15.460428 & 1.23149732 & 0.30787433 \\
\hline & 500000 & 316.334332 & 429.446747 & 1.35757236 & 0.33939309 \\
\hline & 1000000 & 1246.92713 & 1742.66552 & 1.39756805 & 0.34939201 \\
\hline & 2000000 & 4945.62066 & 6692.44327 & 1.35320594 & 0.33830149 \\
\hline & Rata-rata & 815.553336 & 1110.48931 & 1.18013858 & 0.29503464 \\
\hline \multirow{6}{*}{$\begin{array}{l}\text { Bilangan } \\
\text { desimal }\end{array}$} & 100 & 0.000108 & 0.000066 & 0.61111111 & 0.15277778 \\
\hline & 1000 & 0.002679 & 0.002563 & 0.95670026 & 0.23917507 \\
\hline & 10000 & 0.116352 & 0.143129 & 1.23013786 & 0.30753446 \\
\hline & 50000 & 2.855971 & 3.536559 & 1.23830354 & 0.30957589 \\
\hline & 100000 & 11.974052 & 14.445506 & 1.20640081 & 0.3016002 \\
\hline & 500000 & 304.608218 & 411.902765 & 1.35223786 & 0.33805947 \\
\hline
\end{tabular}


C2020 Ilmu Komputer Unila Publishing Network all rights reserved

\begin{tabular}{rrrrr}
\hline 1000000 & 1259.19215 & 1678.07175 & 1.33265741 & 0.33316435 \\
\cline { 2 - 6 } 2000000 & 5420.82996 & 6975.38304 & 1.286774 & 0.3216935 \\
\cline { 2 - 5 } Rata-rata & 874.947435 & 1135.43567 & 1.15179036 & 0.28794759 \\
\hline
\end{tabular}

\section{iv. Analisis Pengujian Algoritma Selection Sort dengan Empat Prosesor}

Pada Tabel 5 dapat dilihat bahwa untuk jumlah data di atas 1000 waktu komputasi secara paralel lebih kecil dibandingkan secara serial. Terdapat peningkatan nilai Speed Up dari data $10.000 \mathrm{ke}$ 50.000 , namun mengalami penurunan pada data 100.000. Dengan bertambahnya jumlah data, nilai Speed Up pada algoritma Selection Sort dengan empat prosesor cenderung tidak konstan, tetapi masih menghasilkan nilai Speed Up lebih dari 1. Bila dibandingkan dengan menggunakan dua prosesor, rata-rata nilai Speed $U p$ dari penggunaan empat prosesor adalah sebesar 1,18013858 (data bilangan bulat) dan 1,15179036 (data bilangan desimal), lebih besar dara rata-rata nilai Speed Up dengan dua prosesor yaitu sebesar 0.84208031 (data bilangan bulat) dan 0,83852736 (data bilangan desimal). Hal tersebut diperkirakan karena dipengaruhi oleh overhead time yang lebih besar pada penggunaan dua prosesor dibandingkan dengan empat prosesor. Perbandingan ini menyimpulkan penggunaan empat prosesor algoritma Selection Sort udah tepat untuk komputasi secara paralel.

\section{v. Pengujian Algoritma Selection Sort (3 Komputer)}

Hasil pengujian dari algoritma Selection Sort menggunakan tiga komputer yang saling terhubung dengan total 12 prosesor yang digunakan dengan menguji data bilangan bulat dan bilangan desimal dapat dilihat pada Tabel 6.

Tabel 6. Hasil pengujian algoritma Selection Sort dengan tiga komputer $(p=12)$

\begin{tabular}{|c|c|c|c|c|c|}
\hline Jenis Data & $\begin{array}{l}\text { Banyak } \\
\text { Data (n) }\end{array}$ & (TP) & (TS) & $\begin{array}{c}\text { Speed Up }(\mathrm{S}) \\
\text { TS/TP }\end{array}$ & $\begin{array}{c}\text { Efisiensi } \\
\text { (S/p) }\end{array}$ \\
\hline \multirow{9}{*}{$\begin{array}{l}\text { Bilangan } \\
\text { bulat }\end{array}$} & 100 & 0.030619 & 0.000016 & 0.00052255 & $4.3546 \mathrm{E}-05$ \\
\hline & 1000 & 0.089333 & 0.002568 & 0.02874638 & 0.00239553 \\
\hline & 10000 & 0.192962 & 0.154462 & 0.80047885 & 0.06670657 \\
\hline & 50000 & 2.770201 & 3.60793 & 1.3024073 & 0.10853394 \\
\hline & 100000 & 11.361699 & 14.713537 & 1.29501204 & 0.10791767 \\
\hline & 500000 & 286.754206 & 424.245462 & 1.47947424 & 0.12328952 \\
\hline & 1000000 & 1146.64364 & 1719.6714 & 1.49974354 & 0.12497863 \\
\hline & 2000000 & 4936.88643 & 7231.38792 & 1.46476692 & 0.12206391 \\
\hline & Rata-rata & 798.091137 & 1174.22291 & 0.98389398 & 0.08199116 \\
\hline \multirow{9}{*}{$\begin{array}{l}\text { Bilangan } \\
\text { desimal }\end{array}$} & 100 & 0.030035 & 0.000075 & 0.00249709 & 0.00020809 \\
\hline & 1000 & 0.085306 & 0.005217 & 0.06115631 & 0.00509636 \\
\hline & 10000 & 0.195931 & 0.154523 & 0.78866029 & 0.06572169 \\
\hline & 50000 & 2.755546 & 3.623299 & 1.31491145 & 0.10957595 \\
\hline & 100000 & 11.473691 & 14.800374 & 1.28994009 & 0.10749501 \\
\hline & 500000 & 286.710935 & 423.159648 & 1.47591039 & 0.12299253 \\
\hline & 1000000 & 1390.29461 & 2008.68573 & 1.44479142 & 0.12039928 \\
\hline & 2000000 & 4976.80232 & 7192.09331 & 1.44512336 & 0.12042695 \\
\hline & Rata-rata & 833.543547 & 1205.31527 & 0.9778738 & 0.08148948 \\
\hline
\end{tabular}

\section{vi. Analisis Pengujian Algoritma Selection Sort dengan Tiga Komputer}

Pada pengujian data Algoritma Selection Sort proses pengurutan dengan tiga komputer, terlihat bahwa pada jumlah data 100 hingga 10.000 waktu komputasi secara serial masih lebih kecil. Namun, mulai pada jumlah data 50.000 waktu komputasi secara paralel lebih kecil dari serial. Walaupun terdapat penurunan pada nilai Speed Up di beberapa data, tetapi lebih banyak terjadi peningkatan nilai Speed $U p$ seiring bertambahnya jumlah data. Hal ini diperkirakan semakin 
(C2020 Ilmu Komputer Unila Publishing Network all rights reserved

banyak data yang diproses maka semakin besar pula nilai Speed Up yang dihasilkan meskipun masih terdapat penurunan nilai Speed Up dibeberapa jumlah data tertentu.

\section{vii. Pengujian Algoritma Radix Sort $(\mathrm{p}=2)$}

Hasil pengujian dari algoritma Radix Sort menggunakan dua prosesor dengan menguji data bilangan bulat dan bilangan decimal dapat dilihat pada Tabel 7.

Tabel 7. Hasil pengujian algoritma Radix Sort dengan dua prosesor

\begin{tabular}{|c|c|c|c|c|c|}
\hline Jenis Data & $\begin{array}{l}\text { Banyak } \\
\text { Data (n) }\end{array}$ & (TP) & (TS) & $\begin{array}{c}\text { Speed Up }(\mathrm{S}) \\
\text { TS/TP }\end{array}$ & $\begin{array}{c}\text { Efisiensi } \\
\text { (S/p) }\end{array}$ \\
\hline \multirow{9}{*}{$\begin{array}{l}\text { Bilangan } \\
\text { bulat }\end{array}$} & 100 & 0.000075 & 0.000012 & 0.16 & 0.08 \\
\hline & 1000 & 0.000813 & 0.00045 & 0.55350554 & 0.27675277 \\
\hline & 10000 & 0.009577 & 0.005892 & 0.61522397 & 0.30761199 \\
\hline & 50000 & 0.014058 & 0.014289 & 1.01643192 & 0.50821596 \\
\hline & 100000 & 0.0248 & 0.020013 & 0.80697581 & 0.4034879 \\
\hline & 500000 & 0.121296 & 0.085099 & 0.70158126 & 0.35079063 \\
\hline & 1000000 & 0.245798 & 0.164478 & 0.66915923 & 0.33457961 \\
\hline & 2000000 & 0.684571 & 0.470416 & 0.68716904 & 0.34358452 \\
\hline & Rata-rata & 0.1376235 & 0.09508113 & 0.65125585 & 0.32562792 \\
\hline \multirow{9}{*}{$\begin{array}{l}\text { Bilangan } \\
\text { desimal }\end{array}$} & 100 & 0.000559 & 0.000316 & 0.56529517 & 0.28264758 \\
\hline & 1000 & 0.00106 & 0.000696 & 0.65660377 & 0.32830189 \\
\hline & 10000 & 0.010961 & 0.008212 & 0.74920172 & 0.37460086 \\
\hline & 50000 & 0.055272 & 0.045618 & 0.82533652 & 0.41266826 \\
\hline & 100000 & 0.103651 & 0.071731 & 0.69204349 & 0.34602175 \\
\hline & 500000 & 0.518284 & 0.357915 & 0.69057698 & 0.34528849 \\
\hline & 1000000 & 1.038519 & 0.716015 & 0.68945778 & 0.34472889 \\
\hline & 2000000 & 2.093373 & 1.446426 & 0.69095474 & 0.34547737 \\
\hline & Rata-rata & 0.47770988 & 0.33086613 & 0.69493377 & 0.34746689 \\
\hline
\end{tabular}

viii. Analisis Pengujian Algoritma Radix Sort dengan Dua Prosesor

Pada Tabel 7 dapat dilihat bahwa dari jumlah data 100 hingga 2.000.000 hampir keseluruhan waktu komputasi secara serial lebih kecil dibandingkan secara paralel. Terdapat peningkatan dan penurunan nilai Speed Up yang didapat, tetapi lebih banyak mengalami penurunan seperti pada data 50.000 ke 100.000. Algoritma Radix Sort dengan dua prosesor memiliki persamaan dengan algoritma Selection Sort dengan dua prosesor yang menghasilkan nilai Speed Up tidak konstan naik atau turun dan cenderung dibawah satu. Hal ini membuktikan bahwa algoritma Radix Sort tidak cocok untuk komputasi secara paralel.

\section{ix. Pengujian Algoritma Radix Sort $(p=4)$}

Hasil pengujian dari algoritma Radix Sort menggunakan empat prosesor dengan menguji data bilangan bulat dan bilangan decimal dapat dilihat pada Tabel 8 .

Tabel 8. Hasil pengujian algoritma Radix Sort dengan Empat Prosesor

\begin{tabular}{lrlccc}
\hline Jenis Data & $\begin{array}{c}\text { Banyak } \\
\text { Data (n) }\end{array}$ & (TP) & (TS) & $\begin{array}{c}\text { Speed Up (S) } \\
\text { TS/TP }\end{array}$ & $\begin{array}{c}\text { Efisiensi } \\
\text { (S/p) }\end{array}$ \\
\hline Bilangan & 100 & 0.000089 & 0.000023 & 0.25842697 & 0.06460674 \\
\cline { 2 - 6 } bulat & 1000 & 0.000413 & 0.000241 & 0.58353511 & 0.14588378 \\
\cline { 2 - 6 } & 10000 & 0.003039 & 0.002351 & 0.77360974 & 0.19340244 \\
\cline { 2 - 6 } & 50000 & 0.011395 & 0.011389 & 0.99947345 & 0.24986836 \\
\cline { 2 - 6 } & 100000 & 0.023785 & 0.028994 & 1.21900357 & 0.30475089 \\
\cline { 2 - 6 } & 0.106116 & 0.119522 & 1.12633345 & 0.28158336 \\
\hline
\end{tabular}


C2020 Ilmu Komputer Unila Publishing Network all rights reserved

\begin{tabular}{lrrrrr}
\hline & 2000000 & 0.595473 & 0.597152 & 1.00281961 & 0.2507049 \\
\cline { 2 - 5 } Bilangan & Rata-rata & 0.11918138 & 0.12168263 & 0.87078027 & 0.21769507 \\
\cline { 2 - 5 } desimal & 100 & 0.000602 & 0.000333 & 0.55315615 & 0.13828904 \\
\cline { 2 - 5 } & 1000 & 0.002391 & 0.002122 & 0.88749477 & 0.22187369 \\
\cline { 2 - 5 } & 10000 & 0.011375 & 0.011365 & 0.99912088 & 0.24978022 \\
\hline 50000 & 0.050139 & 0.042497 & 0.84758372 & 0.21189593 \\
\hline 100000 & 0.09084 & 0.092828 & 1.02188463 & 0.25547116 \\
\hline 500000 & 0.454971 & 0.46041 & 1.01195461 & 0.25298865 \\
\cline { 2 - 5 } & 1000000 & 0.917712 & 0.926766 & 1.00986584 & 0.25246646 \\
\cline { 2 - 5 } & 2000000 & 1.845502 & 1.867933 & 1.01215442 & 0.2530386 \\
\cline { 2 - 5 } & Rata-rata & 0.4216915 & 0.42553175 & 0.91790188 & 0.22947547
\end{tabular}

\section{x. Analisis Pengujian Algoritma Radix Sort dengan Empat Prosesor}

Pada Tabel 8 dapat dilihat bahwa untuk jumlah data 100 hingga 50.000 waktu komputasi secara serial masih lebih kecil, sedangkan data 100.000 atau lebih menghasilkan waktu komputasi secara paralel lebih kecil. Terjadi peningkatan dan penurunan pada nilai Speed Up seiring bertambahnya data dan tidak konstan. Namun, perkiraan semakin banyak jumlah data yang diproses maka nilai Speed Up semakin besar pula walaupun tetap terdapat penurunan nilai Speed Up dibeberapa data tertentu.

\section{xi. Pengujian Algoritma Radix Sort (3 Komputer)}

Hasil pengujian dari algoritma Radix Sort menggunakan tiga komputer yang saling terhubung dengan total 12 prosesor yang digunakan dengan menguji data bilangan bulat dan bilangan desimal dapat dilihat pada Tabel 9.

Tabel 9. Hasil pengujian algoritma Radix Sort dengan tiga komputer $(\mathrm{p}=12)$

\begin{tabular}{|c|c|c|c|c|c|}
\hline Jenis Data & $\begin{array}{l}\text { Banyak } \\
\text { Data (n) }\end{array}$ & (TP) & (TS) & $\begin{array}{c}\text { Speed Up }(\mathrm{S}) \\
\text { TS/TP }\end{array}$ & $\begin{array}{l}\text { Efisiensi } \\
\text { (S/p) }\end{array}$ \\
\hline \multirow{9}{*}{$\begin{array}{l}\text { Bilangan } \\
\text { bulat }\end{array}$} & 100 & 0.030564 & 0.000017 & 0.00055621 & 4.6351E-05 \\
\hline & 1000 & 0.08976 & 0.000444 & 0.00494652 & 0.00041221 \\
\hline & 10000 & 0.087047 & 0.003895 & 0.04474594 & 0.00372883 \\
\hline & 50000 & 0.0948 & 0.01901 & 0.20052743 & 0.01671062 \\
\hline & 100000 & 0.106989 & 0.029435 & 0.27512174 & 0.02292681 \\
\hline & 500000 & 0.215582 & 0.111616 & 0.51774267 & 0.04314522 \\
\hline & 1000000 & 0.316219 & 0.215722 & 0.68219177 & 0.05684931 \\
\hline & 2000000 & 0.799083 & 0.689044 & 0.8622934 & 0.07185778 \\
\hline & Rata-rata & 0.2175055 & 0.13364788 & 0.32351571 & 0.02695964 \\
\hline \multirow{9}{*}{$\begin{array}{l}\text { Bilangan } \\
\text { desimal }\end{array}$} & 100 & 0.030334 & 0.000199 & 0.0065603 & 0.00054669 \\
\hline & 1000 & 0.08846 & 0.002113 & 0.0238865 & 0.00199054 \\
\hline & 10000 & 0.10002 & 0.008593 & 0.08591282 & 0.0071594 \\
\hline & 50000 & 0.122803 & 0.047832 & 0.38950189 & 0.03245849 \\
\hline & 100000 & 0.170877 & 0.095422 & 0.55842507 & 0.04653542 \\
\hline & 500000 & 0.50877 & 0.467506 & 0.91889459 & 0.07657455 \\
\hline & 1000000 & 0.922676 & 0.941322 & 1.02020861 & 0.08501738 \\
\hline & 2000000 & 2.020126 & 2.055131 & 1.01732813 & 0.08477734 \\
\hline & Rata-rata & 0.49550825 & 0.45226475 & 0.50258974 & 0.04188248 \\
\hline
\end{tabular}

\section{xii. Analisis Pengujian Algoritma Radix Sort dengan Tiga Komputer}

Pada Tabel 9 dapat dilihat bahwa untuk jumlah data 100 hingga 2.000.000 menghasilkan nilai Speed Up yang cenderung dibawah satu. Namun, seiring bertambahnya jumlah data nilai Speed $U p$ cenderung selalu naik. Hal ini berarti proses paralel yang dilakukan memiliki hasil yang lebih baik apabila data berjumlah sangat banyak dibandingkan penggunaan dua prosesor maupun empat prosesor. 
Vol. 8 No. 2, 2020

Jurnal Komputasi

(C2020 Ilmu Komputer Unila Publishing Network all rights reserved

\section{c. Hasil Perbandingan Speed Up}

Hasil perbandingan Speed $U p$ dari keenam skenario pengujian tersebut dapat dilihat dalam bentuk grafik seperti yang dapat dilihat pada Gambar 8 dan Gambar 9 berikut.

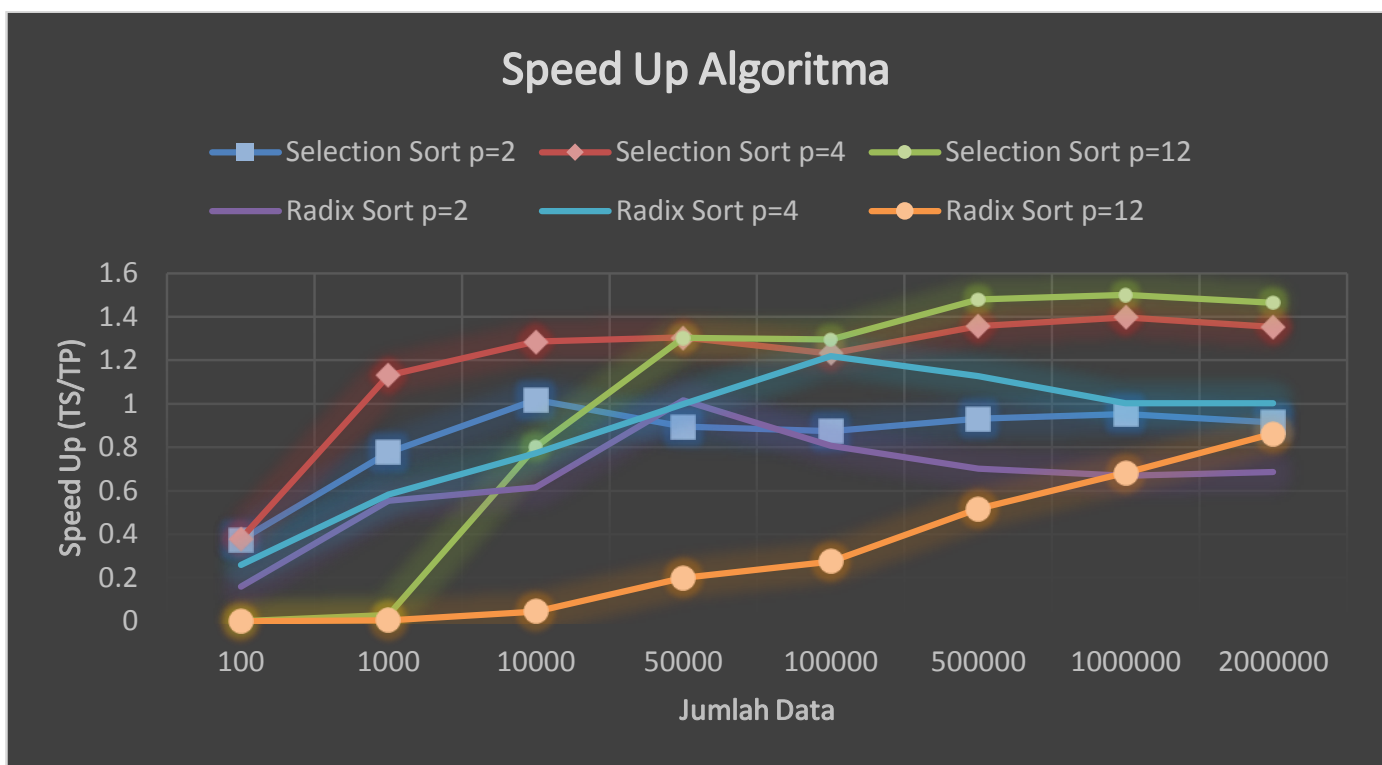

Gambar 8. Grafik perbandingan Speed Up algoritma Selection Sort dan Radix Sort untuk data bilangan bulat

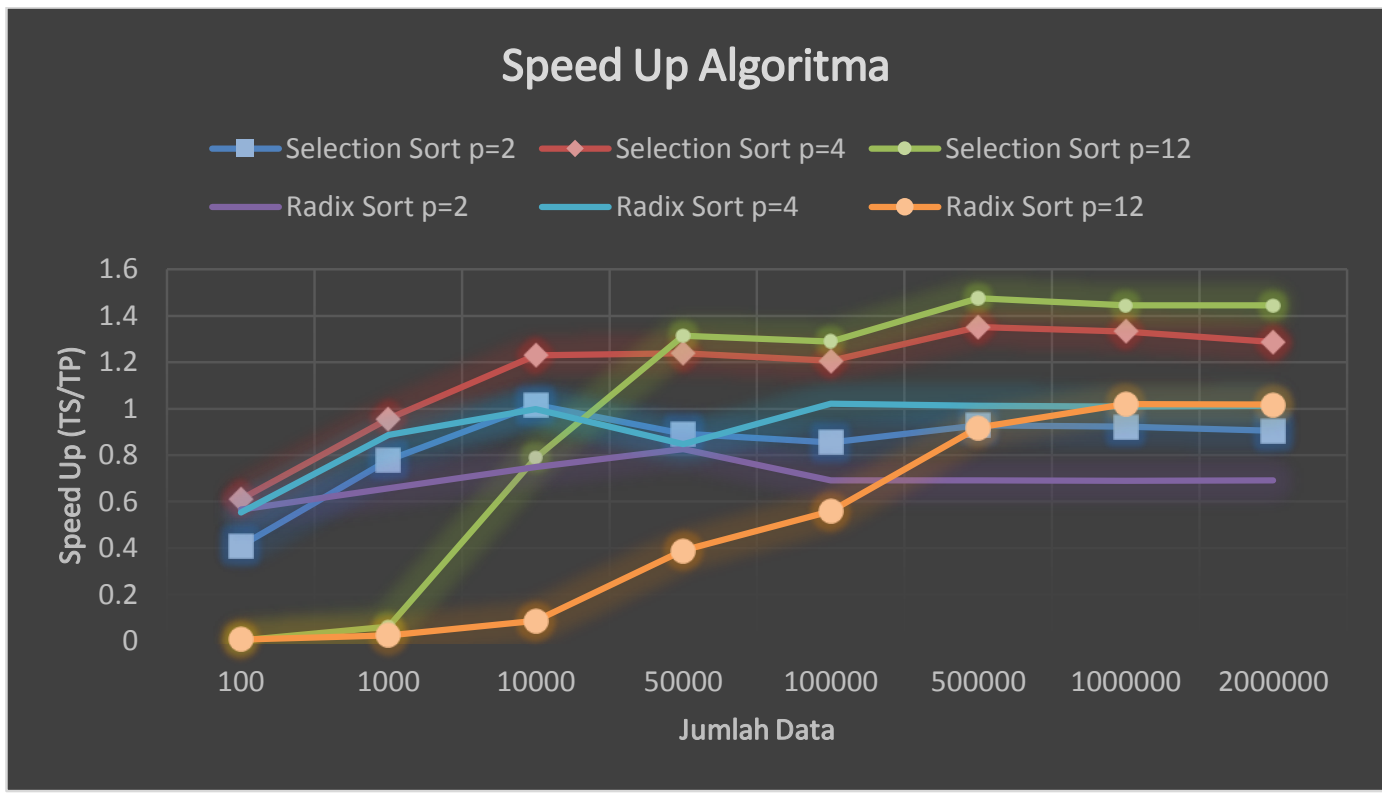

Gambar 9. Grafik perbandingan Speed Up algoritma Selection Sort dan Radix Sort untuk data bilangan desimal

\section{d. Hasil Perbandingan Efisiensi}

Hasil perbandingan Efisiensi dari keenam scenario pengujian tersebut dapat dilihat dalam bentuk grafik seperti yang dapat dilihat pada Gambar 10 dan Gambar 11 berikut. 
(C2020 Ilmu Komputer Unila Publishing Network all rights reserved

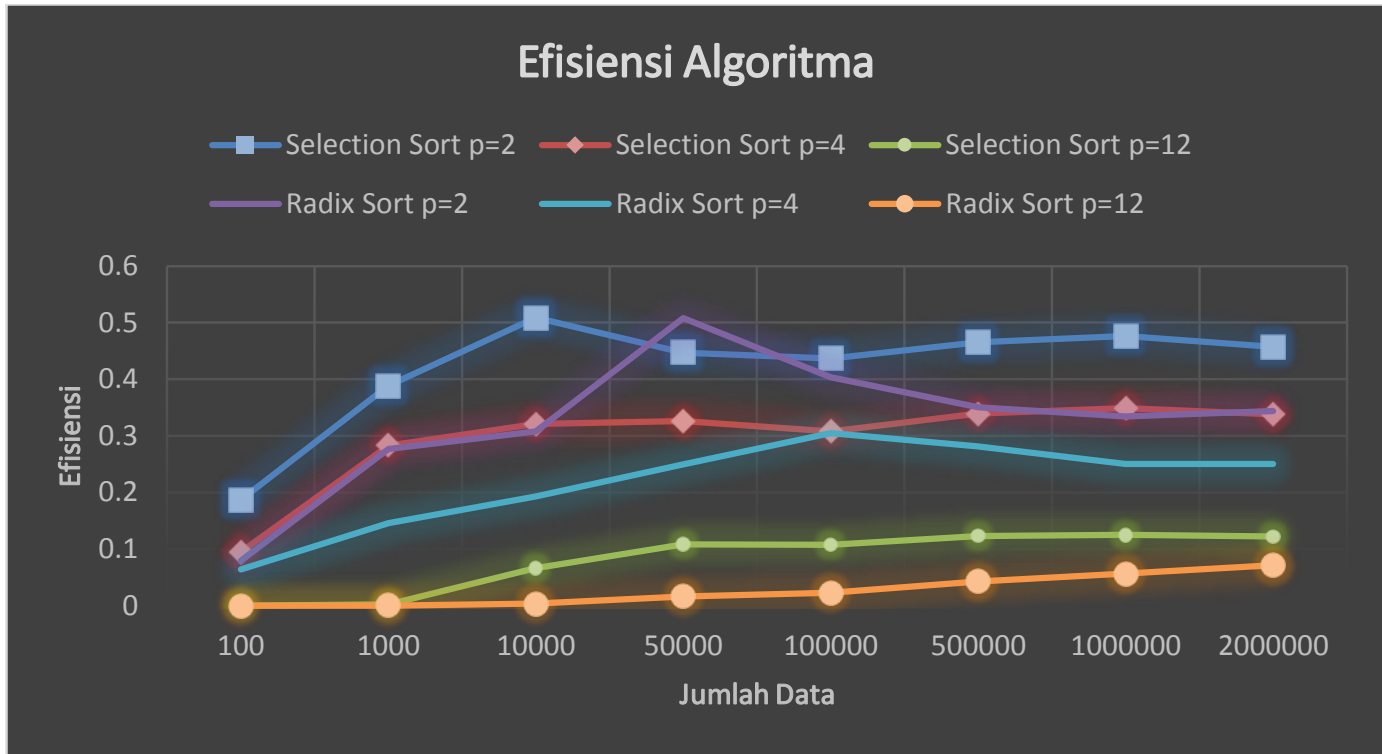

Gambar 10. Grafik perbandingan Efisiensi algoritma Selection Sort dan Radix Sort untuk data bilangan bulat

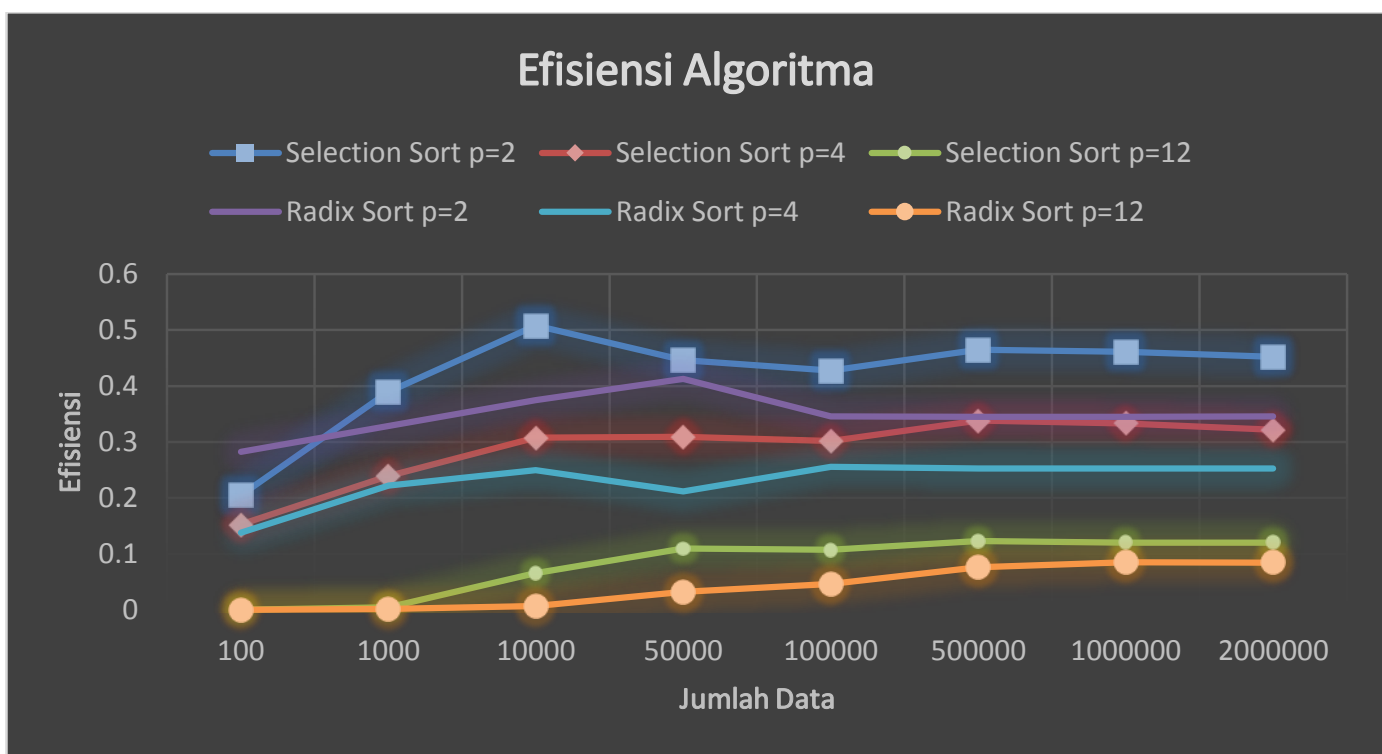

Gambar 11. Grafik perbandingan Efisiensi algoritma Selection Sort dan Radix Sort untuk data bilangan desimal

\section{e. Hasil Perbandingan Efisiensi}

Pada proses pengujian menggunakan tiga komputer yang saling terhubung, penggunaan sumber daya dalam proses komputer Slave A dan Slave B dapat dilihat pada Gambar 12, Gambar 13, Gambar 14, dan Gambar 15. 
Vol. 8 No. 2, 2020

Jurnal Komputasi

(C2020 Ilmu Komputer Unila Publishing Network all rights reserved

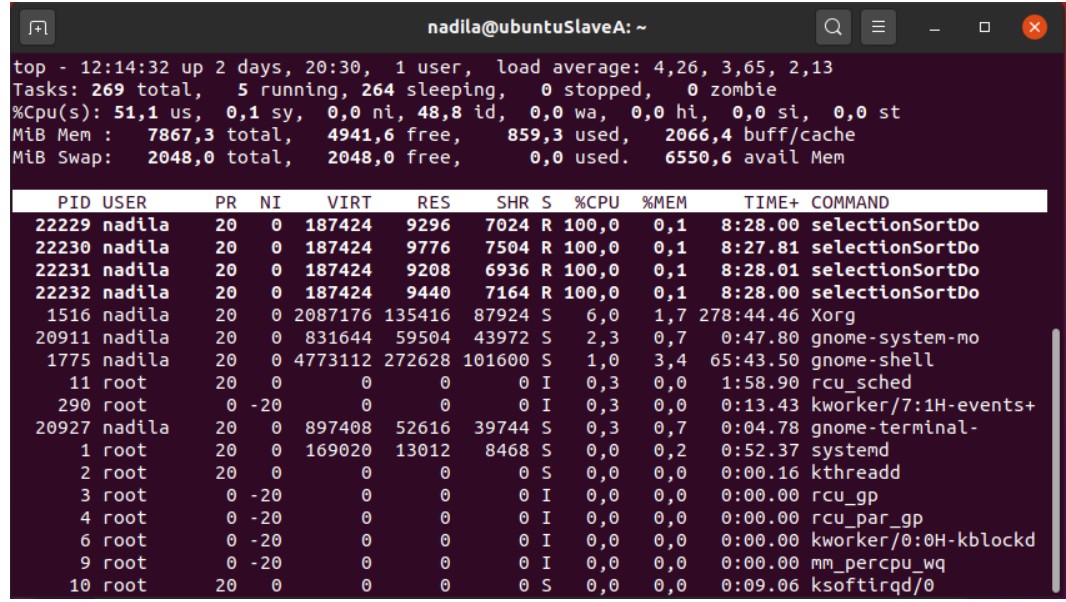

Gambar 12. Tampilan proses monitor dan penggunaan sumber daya sistem di PC Slave A pada saat running program data 2.000 .000 dengan tiga komputer (12 prosesor)

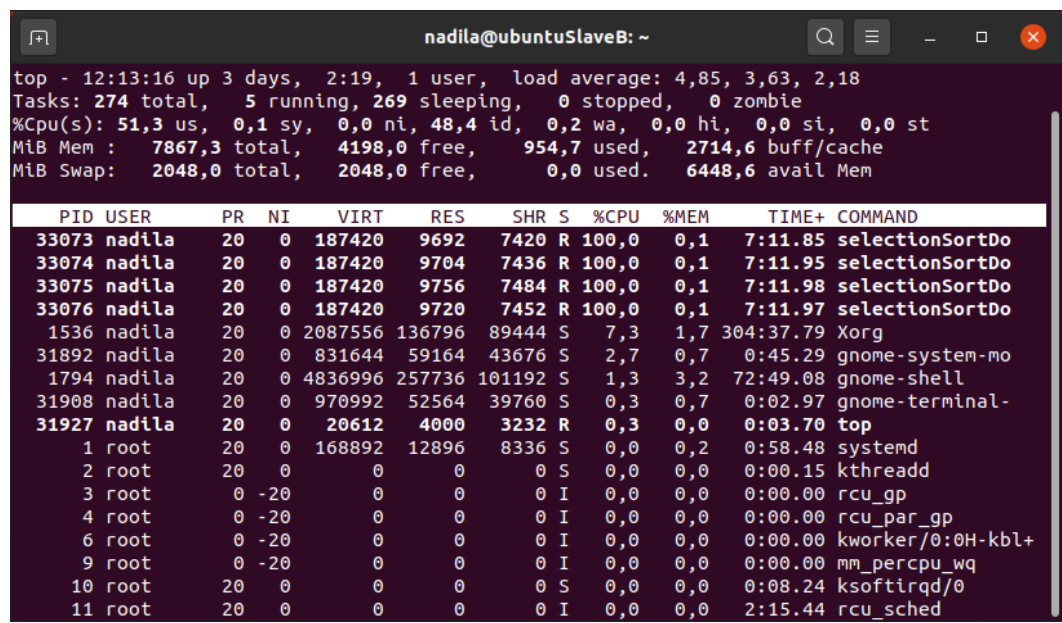

Gambar 13. Tampilan proses monitor dan penggunaan sumber daya sistem di PC Slave B pada saat running program data 2.000 .000 dengan tiga komputer (12 prosesor)

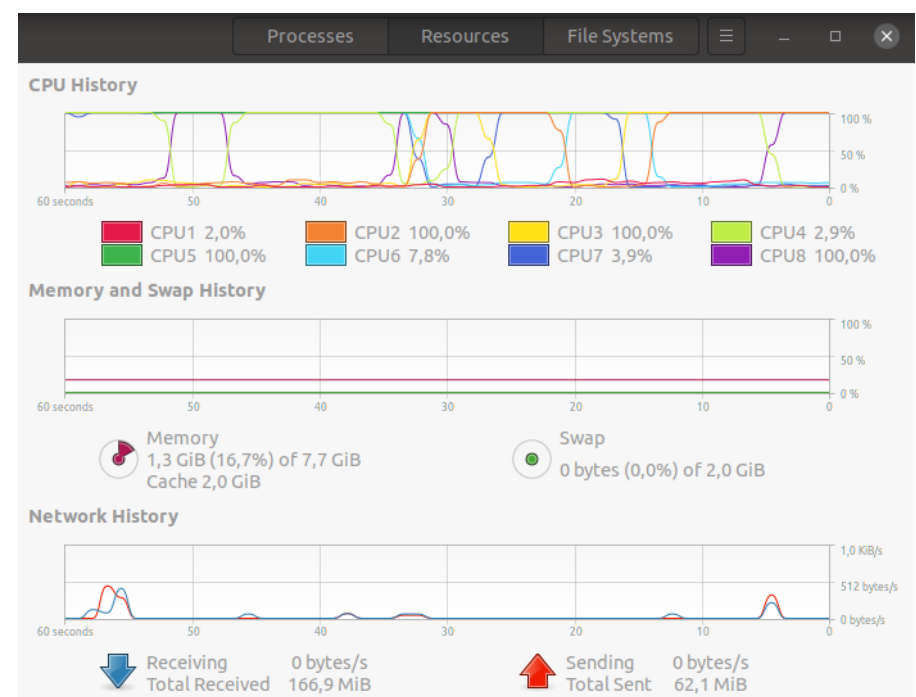

Gambar 14. Tampilan sistem monitor penggunaan sumber daya di PC Slave A dalam proses komputasi dengan tiga komputer 


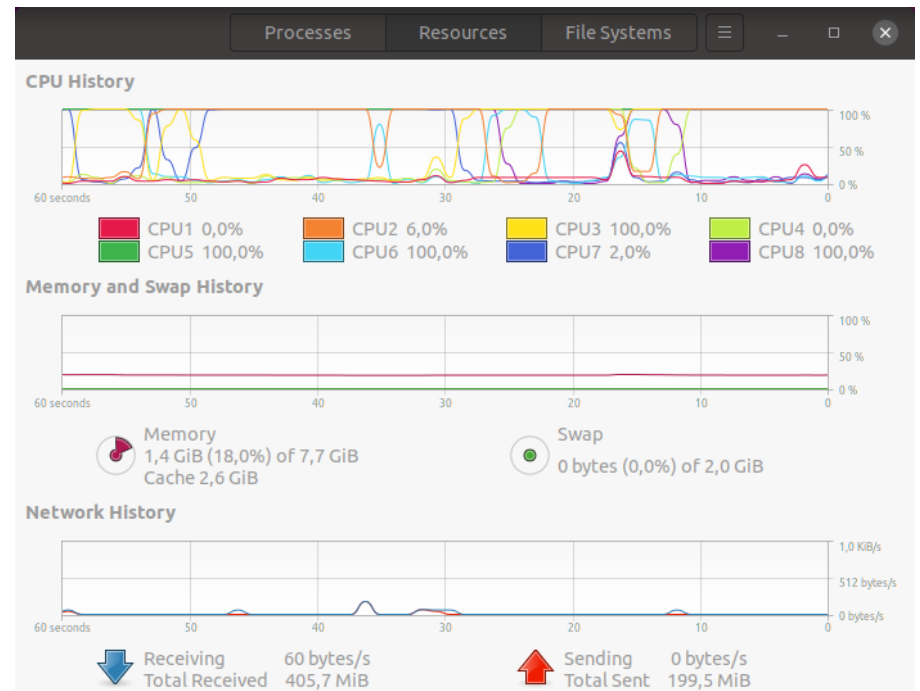

Gambar 15. Tampilan sistem monitor penggunaan sumber daya di PC Slave B dalam proses komputasi dengan tiga komputer

\section{KESIMPULAN}

Berdasarkan hasil pengujian yang dilakukan dapat mengambil simpulan sebagai berikut.

1. Secara umum untuk jumlah data yang tidak terlalu besar, waktu komputasi serial berjalan lebih cepat bila dibandingkan dengan waktu komputasi secara paralel.

2. Algoritma Selection Sort maupun Radix Sort dengan dua prosesor tidak menghasilkan nilai Speed Up baik yang berarti tidak cocok untuk komputasi secara paralel. Hal ini disebabkan karena komunikasi paralel mengalami overhead time yang besar.

3. Algoritma Selection Sort dengan empat prosesor menghasilkan nilai Speed Up cenderung konstan diatas 1 yang berarti waktu eksekusi komputasi paralel lebih cepat dibandingkan komputasi serial.

4. Algoritma Radix Sort dengan empat prosesor untuk jumlah data lebih dari 50.000 terbilang menghasilkan nilai Speed Up yang baik. Diperkirakan nilai Speed Up akan semakin besar seiring bertambahnya jumlah data, walaupun tetap terdapat penurunan nilai Speed Up dibeberapa data tertentu.

5. Algoritma Selection Sort dengan tiga komputer menghasilkan nilai Speed Up yang hampir sama dengan algoritma Radix Sort dengan empat prosesor untuk jumlah data yang relatif kecil waktu komputasi secara serial masih terbilang lebih cepat, tetapi untuk data besar waktu komputasi secara paralel lebih cepat dibandingkan komputasi secara serial.

6. Algoritma Radix Sort dengan tiga komputer menghasilkan nilai Speed Up cenderung selalu meningkat tanpa mengalami penurunan sama sekali. Namun, dari hasil nilai Speed Up ratarata waktu komputasi secara serial masih terbilang jauh lebih cepat dibandingkan komputasi secara paralel. Disimpulkan bahwa untuk jumlah data dibawah 1.000.000, algoritma Radix Sort belum memerlukan penggunaan tiga komputer untuk komputasi secara paralel.

7. Hasil nilai Efesiensi yang didapat dari semua skenario pengujian membuktikan bahwa penggunaan dengan dua prosesor masih tergolong paling efesien dibandingkan empat prosesor dan 3 komputer baik itu algoritma Selection Sort maupun Radix Sort.

8. Simpulan terakhir, apabila jumlah data yang diproses terbilang kecil sebaiknya hanya menggunakan dua prosesor saja dengan menggunakan komputasi secara serial. Namun, jika data sudah memasuki jutaan sebaiknya menggunakan algoritma Radix Sort dengan empat prosesor secara paralel. Dan apabila data yang diproses sudah sangat besar seperti puluhan juta, sebaiknya menggunakan algoritma Radix Sort dengan 3 komputer atau lebih secara paralel. 
Vol. 8 No. 2, 2020

Jurnal Komputasi

(C2020 Ilmu Komputer Unila Publishing Network all rights reserved

\section{REFERENSI}

[1]. Reed D., Fujimoto R.M. 1987. Multicomputer Networks: Message-Based Parallel Processing. MIT Press.

[2]. Prianto B. 2008. Cluster Komputer Sebagai Pengganti Super Komputer Tunggal untuk Pemodelan Kimia Komputasi. Berita Dirgantara Vol 9 No 1.

[3]. Singh I., Sch. J. Eng. Tech. 2013. Review on Parallel and Distributed Computing. Scholars Journal of Engineering and Technology (SJET).

[4]. Yusman M., Aristoteles, \& Anie Rose Irawati. 2012. Analisis Komputasi Paralel dan Serial Pada Algoritma Merge Sort. Jurnal Sains MIPA Vol 18 No 1.

[5]. Fauzi, Indrayana. 2005. Perbandingan Kecepatan/Waktu Komputasi Beberapa Algoritma Pengurutan (Sorting). Institut Teknologi Bandung.

[6]. Utami E., Raharjo S., \& Sukrisno. 2007. Struktur Data Konsep \& Implementasinya dalam Bahasa $C$ \& Free Pascal di GNU/LINUX. Yogyakarta: Graha Ilmu.

[7]. Sitepu R.R., Machudor Y., \& Febi E.F. 2017. Implementasi Algoritma Bubble Sort dan Selection Sort Menggunakan Arraylist Multidimensi Pada Pengurutan Data Multi Prioritas. Jurnal Komputasi Vol 5 No 1.

[8]. Wibawa I.P.A.P., Dwi G., \& Made S. 2018. Komputasi Paralel Menggunakan Model Message Passing Pada SIM RS (SIstem Informasi Manajemen Rumah Sakit). Majalah Ilmiah Teknologi Elektro Vol 17 No 3.

[9]. Setyawan C.A. 2015. Metode Eliminasi Gauss dengan Komputasi Parallel. Makalah IF2123 Aljabar Geometri.

[10]. Barney Blaise. 2011. Message Passing Interface (MPI). Lawrence Livermore Nation Laboratory. Dikutip 22 September 2019 dari Computing 1lnl: https://computing.llnl.gov/tutorials/mpi/.

[11]. Liswandini Intan, Budhi Irawan, \& Irzaman. 2005. Studi Komparatif Antara Paralel Virtual Machine (PVM) dan Message Passing Interface (MPI) dengan Memanfaatkan Local Area Network (LAN). Universitas Komputer Indonesia.

[12]. Yahya S.Y. 2014. Analisa Perbandingan Algoritma Bubble Sort dan Selection Sort dengan Perbandingan Eksponensial. Jurnal Pelita Informatika Budi Darma Vol VI No 3.

[13]. Cormen T., C. Leiserson, R. Rivest, \& C. Stein. 2001. Introduction to Algorithms. McGraw Hill, pp.320-330.

[14]. Alfatwa D.F., Eriek R.S.P., \& Fahris M.A. 2015. Implementasi Algoritma Radix Sort dalam Berbagai Kasus Bilangan Dibandingkan Algoritma Pengurutan yang lain. Institut Teknologi Bandung. 